\title{
Unraveling the bacterial diversity of Cangar Hot Spring, Indonesia by Next Generation Sequencing of 16S rRNA gene
}

\author{
ALMANDO GERALDI ${ }^{1,2, \bullet}$ CHIA CHAY TAY ${ }^{3}$, NI'MATUZAHROH ${ }^{1,2}$, FATIMAH $^{1,2}$, \\ WAN NURHAYATI WAN HANAFI ${ }^{3}$ \\ ${ }^{1}$ Departement of Biology, Faculty of Science and Technology, Universitas Airlangga. Jl. Mulyosari, Surabaya 60115, East Java, Indonesia. \\ Tel. +62-31-5936501, Fax.: +62-31-5926804, `email: almando.geraldi@ fst.unair.ac.id \\ ${ }^{2}$ University-Center of Excellence-Research Center for Bio-Molecule Engineering, Universitas Airlangga J1. Mulyosari, Surabaya 60115, East Java, \\ Indonesia \\ ${ }^{3}$ Faculty of Applied Sciences, Universiti Teknologi MARA (UiTM). Shah Alam, Selangor 40450, Malaysia
}

Manuscript received: 28 June 2021. Revision accepted: 30 August 2021.

\begin{abstract}
Geraldi A, Tay CC, Ni'matuzahroh, Fatimah, Hanafi WNW. 2021. Unraveling the bacterial diversity of Cangar Hot Spring, Indonesia by Next Generation Sequencing of $16 S$ rRNA gene. Biodiversitas 22: 4060-4066. This study is the first attempt at using the Next Generation Sequencing (NGS) method with 16S rRNA to understand the bacterial community structure in an Indonesian hot spring. This study aims to unravel the bacterial diversity of the Cangar Hot Spring as one of the most explored natural hot springs in East Java, Indonesia. We found Proteobacteria and Bacteroidetes as the two most abundant phyla. We discovered the first occurrence of genera Cloacibacterium and Methylobacillus in the hot spring ecosystem, which was the most dominant genera at Cangar Hot Spring. We also found several potential bacteria for bioindustry and bioremediation, such as Acinetobacter junii and Pseudomonas alcaligenes. Besides that, we also observed opportunistic pathogens from genera Comamonas and Vogesella. This study result will provide valuable information for further bioprospecting of bacteria with commercial potential and the development of health and safety measures in the Cangar Hot Spring, among others. Hopefully, this report would encourage the use of NGS technology for studying other hot springs in Indonesia.
\end{abstract}

Keywords: Aquatic ecosystems, hot spring, bacteriome, next-generation sequencing, 16S rRNA

\section{INTRODUCTION}

Hot springs is one of the extreme ecosystem characterized by outflowing water with a temperature above $36.7^{\circ} \mathrm{C}$ (Jiang et al. 2018, Pentecost et al. 2003). In the hot spring ecosystem, thermophilic microorganisms such as Archaea and bacteria can thrive well ( $\mathrm{Li}$ et al. 2020) because of their ability to survive in hightemperature conditions. These thermophilic microorganisms are of great interest since they are able to produce thermostable enzymes and biomolecules such as biosurfactants, polysaccharides, and antibiotics, which are industrially important (Atalah et al. 2019, Di Lorenzo et al. 2014, Geraldi et al. 2019a, Kambourova 2018, Mahajan and Balachandran 2017, Sahoo et al. 2020, Teta et al. 2017). These microorganisms can also be utilized in bioremediation processes such as the biodegradation of hydrocarbons and removal of heavy metals, and also biofuel production (Castro et al. 2019, Di Donato et al 2019, Ebaid et al. 2019, Geraldi et al. 2019b, Jardine et al. 2018, Orellana et al. 2018).

Located in the Pacific Ring of Fire, Indonesia is a country rich in geothermal sites, with 256 hot springs identified across the archipelago (Darma et al. 2010, Yohandini et al. 2015). Since 1991, the exploration and bioprospecting of thermophilic microorganisms from hot springs have been done in Indonesia, mostly using culturebased approaches (Huber et al. 1991). These explorations have successfully isolated various thermostable enzymes (cellulase, amylase, chitinase, protease)-producing bacteria, mostly from the order Bacillales (Geraldi et al. 2019c, Lischer et al. 2020, Wang et al. 2012). Among the studied hot springs in Indonesia, Cangar Hot Spring in East Java is one of the most microbiologically explored. From the Cangar Hot Spring, bacteria strains (i.e., Bacillus subtilis subsp. inaquosorum strain and two Bacillus licheniformis strains) with the potential to produce thermostable biosurfactants and enzymes were isolated (Chrisnasari et al. 2018, Geraldi et al. 2019b, 2019c, Ibrahim et al. 2013, Rashid et al. 2013).

Since $99 \%$ of microbial species are unculturable (Amin et al. 2017, Bodor et al. 2020), culture-independent approaches are needed to explore and utilize thermophilic microorganism biodiversity from hot springs. Previous studies in hot springs at Tanjung Sakti, Gedongsongo, and Kamojang area, Indonesia (Aditiawati et al. 2009, Aminin et al. 2008, Yohandini et al. 2015), showed that Denaturing Gradient Gel Electrophoresis (DGGE) and 16S rRNA gene sequencing was successful in revealing the unculturable microorganisms. However, up to our knowledge, there is no report on the utilization of Next Generation Sequencing (NGS) technology as a cutting-edge and powerful tool for analyzing microbial communities. NGS approach on $16 \mathrm{~S}$ rDNA amplicons obtained from Cangar Hot Spring metagenomic DNA enables the comprehensive analysis of microbial populations in the hot spring. This study is 
among the first to reveal bacterial community structure in an Indonesian hot spring using NGS, including the most dominant taxa and microbe species with potential application. Results from this study would provide insight into the microbiology of Cangar Hot Springs, including useful and harmful microorganisms. Furthermore, this work would be the first step in building a database of microorganisms of hot springs in Indonesia, as well as would provide a basis for comparison with other hot springs around the world.

\section{MATERIALS AND METHODS}

\section{Sampling Site and Sample Collection}

The Cangar Hot Spring is a recreational hot spring in the Raden Soerjo Forest Park, Batu, East Java, Indonesia, at $112^{\circ} 32^{\prime} 0^{\prime \prime} \mathrm{E}$ longitude and $7^{\circ} 44^{\prime} 31^{\prime \prime} \mathrm{S}$ latitude. Samples of water and sediment mix were collected from several locations of the hot spring and mixed in sterile insulated water bottles. Collected samples were immediately transported to the laboratory for further analyses. The measurements of temperature and $\mathrm{pH}$ of the samples were done onsite and averaged at $50.1^{\circ} \pm 1.2^{\circ} \mathrm{C}$ and $6.3 \pm 0.2$, respectively.

\section{S rRNA gene high-throughput amplicon sequencing}

Samples were extracted for their total metagenomic DNA using Cetyltrimethylammonium Bromide (CTAB)based method (Jiang et al. 2013). Extracted DNA from the samples was diluted with sterile deionized water to $1 \mathrm{ng} / \mu \mathrm{L}$. The extracted DNA sample was sent to Novogene AIT Genomics, Singapore, for high-throughput amplicon sequencing targeting the V3-V4 conserved regions in the prokaryotic 16S rRNA gene. Polymerase Chain Reaction (PCR) was conducted to amplify the V3-V4 region of $16 \mathrm{~S}$ rRNA gene using primer $341 \mathrm{~F}$ (5'CCTAYGGGRBGCASCAG-3') and 806R (5'GGACTACNNGGGTATCTAAT-3') with Phusion ${ }^{\circledR}$ HighFidelity PCR Master Mix (New England Biolabs). Sequencing libraries were generated using Ion Plus Fragment Library Kit (Thermo Fisher Scientific) according to manufacturer instructions. The library quality was assessed using Qubit ${ }^{\circledR}$ 2.0 Fluorometer (Thermo Fisher Scientific). Finally, the library was sequenced on an IonS5 $^{\mathrm{TM}}$ XL system platform (Thermo Fisher Scientific).

\section{Sequencing data processing}

Based on the samples' unique barcode, paired-end reads were assigned, and then the samples were truncated by cutting off the barcode and primer sequences and were merged using FLASH v1.2.7 (Magoč and Salzberg 2011). Next, the filtration of resulting raw tags was done for assuring quality control using QIIME v1.7.0 (Caporaso et al. 2010). Chimera sequence was removed based on the comparison with Gold reference database using UCHIME algorithm (Edgar et al. 2011, Haas et al. 2011). The UPARSE software was used to analyze the obtained effective tags (Edgar 2013). The Operational Taxonomic
Units (OTU) was assigned to effective tags sequences with similarity level $\geq 97 \%$. Representative sequences for each OTU were then annotated using MOTHUR software against the small ribosomal subunit rRNA SILVA database using a threshold of 0.8-1 (Schloss et al. 2009, Quast et al. 2012). The phylogenetic relationship of different OTUs was analyzed using MUSCLE software v.3.8.31 (Edgar 2004). Finally, the six indices (i.e., observed species, Chao1 estimator, ACE estimator, Shannon Index, Simpson Index, and the Good's coverage) related to alpha diversity were calculated using QIIME v1.7.0 and displayed using $\mathrm{R}$ software.

\section{RESULTS AND DISCUSSION}

\section{Bacterial community structure based on next- generation sequencing analysis}

The NGS analysis results revealed Cangar Hot Spring harbors a wealth of different microbial species. There were 539 species observed, with Shannon-Wiener diversity index of 5.642, and species richness estimators Chao1 and ACE of 540.615 and 540.629, respectively (Table 1). Good's coverage of the results was $100 \%$, implying that the sequencing provided adequate classification diversity coverage. The whole Prokaryotic microorganism community structure of Cangar Hot Spring is presented in the Krona graph (Figure 1).

\section{Taxonomic composition of bacterial communities in Cangar Hot Spring}

There were 28 bacterial phyla detected in the sequencing results (Figure 2). The Cangar Hot Spring bacterial community structure at phylum level was dominated by the Gram-negative phyla Proteobacteria $(58.05 \%$ of total OTUs in the sample), Bacteroidetes (29.58\%), and photosynthetic thermophiles Chloroflexi (2.24\%). Gram-positive phyla represented mostly by Firmicutes $(10.51 \%)$ and Actinobacteria $(0.75 \%)$. Other phyla such as nitrifying Nitrospirae $(0.54 \%)$, photosynthetic Cyanobacteria $(0.24 \%)$, and Chlorobi (0.07\%), iron-reducing Deferribacteres $(0.16 \%)$, extremophiles Deinococcus $(0.006 \%)$ were found less abundant.

The ten most abundant families found in the samples collected were dominated by Gram-negative groups such as Flavobacteriaceae (19.11\%), Methylophilaceae (17.97\%), and Pseudomonadaceae (13.86\%), while Gram-positive only represented by Clostridiaceae $1(0.19 \%)$ (Figure 3).

Table 1. Number of observed species diversity index (ShannonWeiner) and species richness (Chao1, Abundance based coverage estimator (ACE)) estimators in Cangar Hot Spring, Batu, East Java, Indonesia

\begin{tabular}{ccccc}
\hline $\begin{array}{c}\text { Observed Shannon-Wiener } \\
\text { species }\end{array}$ & index & Chao1 & ACE & $\begin{array}{c}\text { Good's coverage } \\
\text { estimator }\end{array}$ \\
\hline 539 & 5.642 & 540.615540 .629 & 100 \\
\hline
\end{tabular}




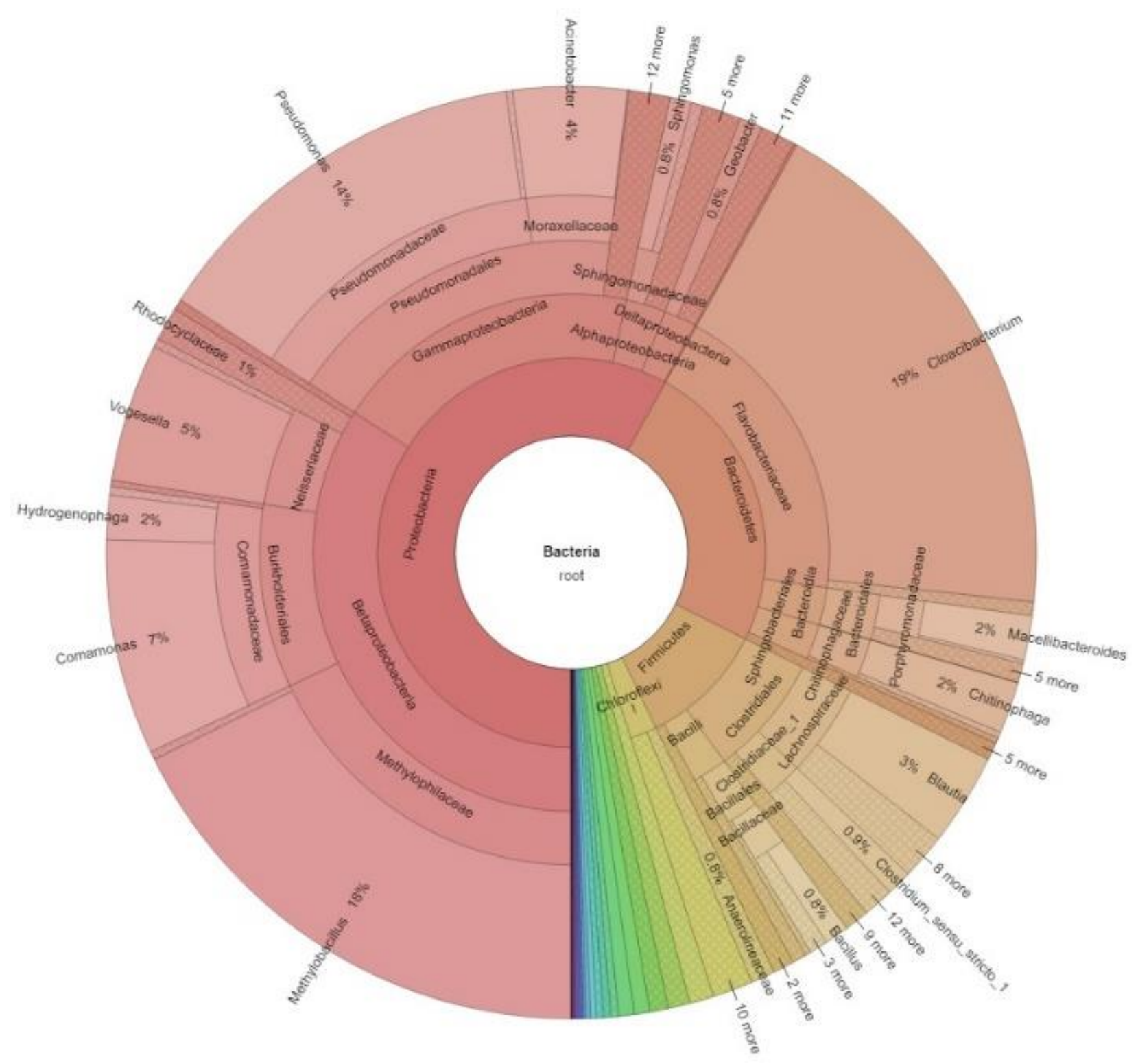

Figure 1. The whole bacterial community distribution in the Cangar Hot Spring, Batu, East Java, Indonesia is represented by the Krona graph. The relative abundance at the level of phylum, class, order, and genus was shown in the graph

At the genus level, Gram-negative Cloacibacterium (18.64\%), Methylobacillus (17.69\%), and Pseudomonas (13.64\%) were the most dominant genera in Cangar Hot Spring with Blautia as the only Gram-positive genus in the top ten most abundant genera (Figure 4). Some identified species were Gram-negative Comamonas testosteroni (3.70\%), Comamonas aquatica (3.54\%), Acinetobacter junii (2.37\%), Terrimonas sp. 16-45A (1.79\%), Acinetobacter johnsonii $(0.93 \%)$, Vogesella perlucida $(0.59 \%)$, and Pseudomonas alcaligenes (0.33\%), and Gram-positive Ruminococcus sp. 51 39BFAA (2.86\%).

\section{Discussion}

Java, the world's most populous island, is also one area with the most active volcanoes in Indonesia (Daryono et al. 2019, Purnomo and Pichler 2014). Consequently, there are many geothermal areas on the island, including Arjuno-Welirang Volcanic Complex in East Java, where Cangar Hot Spring is located (Putra et al. 2019). Previous studies (Daud et al. 2019, Martadiastuti et al. 2017) mentioned Cangar Hot Spring has a temperature range between $39.5-53^{\circ} \mathrm{C}$, and a $\mathrm{pH}$ ranged between $5.2-6.5$ (consistent with our measurement results) with bicarbonate rich water.

There were already several explorations on useful microorganisms collected from Cangar Hot Spring. However, there was no study on the hot spring's microbial community structure analysis using a more novel method, such as the NGS yet. In this study, NGS was employed to perform 16S rRNA metagenomic analysis for unraveling bacterial diversity in Cangar Hot Spring, especially pathogenic bacteria and bacteria with potential commercial applications 


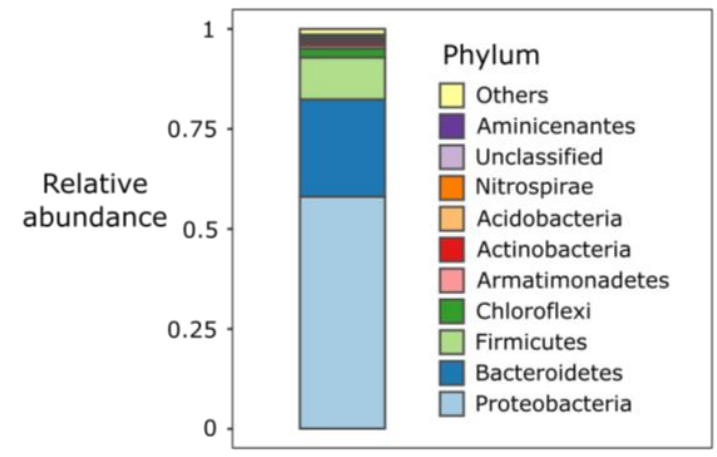

Figure 2. Bacterial Operational Taxonomic Unit (OTU) relative abundance at phylum level recovered from the Cangar Hot Spring, Batu, East Java, Indonesia. The total relative abundance of bacterial phyla besides the ten most abundant phyla is represented by "Others". Proteobacteria was the predominant phylum in the sample.

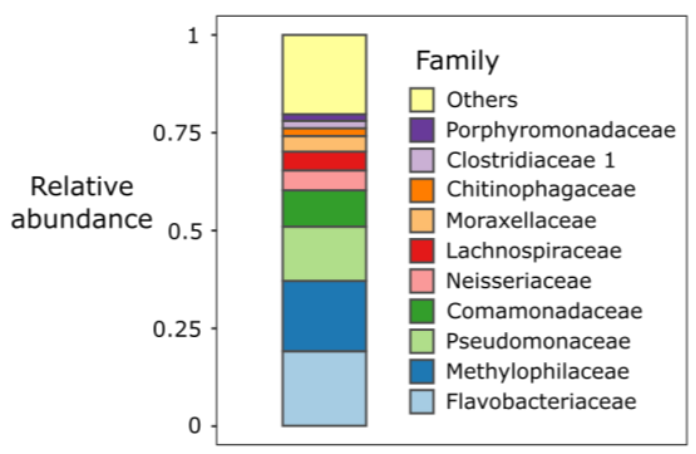

Figure 3. The bacterial OTU relative abundance at family level recovered from the Cangar Hot Spring, Batu, East Java, Indonesia. The total relative abundance of bacterial families besides the ten most abundant families is represented by "Others". Flavobacteriaceae and Methylophilaceae were the two most dominant families in the sample.

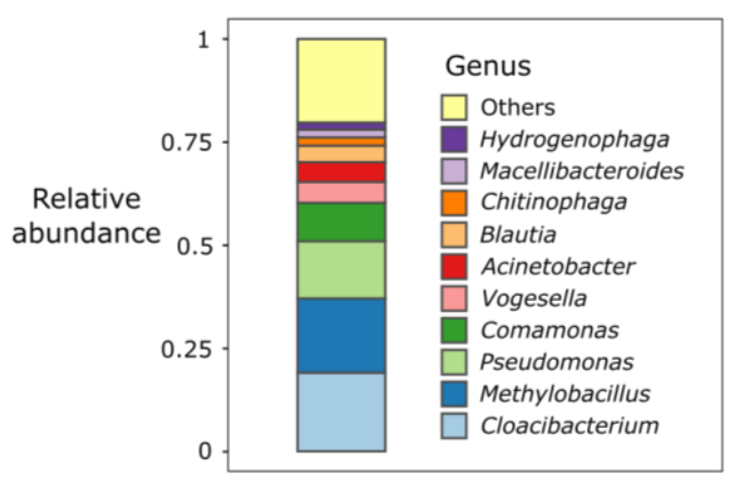

Figure 4. The bacterial OTU relative abundance at genus level recovered from the Cangar Hot Spring, Batu, East Java, Indonesia. The total relative abundance of bacterial genera besides the ten most abundant genera is represented by "Others". Cloacibacterium and Methylobacillus were the two most dominant genera in the sample.
In this study, the dominant components of the bacterial community structure of Cangar Hot Spring were Gram-negative bacteria, i.e., members of Proteobacteria, Bacteroidetes, and Chloroflexi phyla (>89\% OTU). The dominance of Proteobacteria phylum was also reported from similar studies using 16S rRNA analysis in hot springs from a geographically distant area with moderate to high temperatures $\left(37-95^{\circ} \mathrm{C}\right)$, such as Ayer Hangat hot spring, Malaysia $\left(45^{\circ} \mathrm{C}, \mathrm{pH} 7.1\right)$; Coamo hot spring, Puerto Rico $\left(47^{\circ} \mathrm{C}, \mathrm{pH} 8.2\right)$; Burgas hot spring, Spain $\left(66.3^{\circ} \mathrm{C}, \mathrm{pH}\right.$ 7.6); Hammam Essalihine hot spring, Algeria $\left(70^{\circ} \mathrm{C}, \mathrm{pH}\right.$ 7.3); and Soldhar hot spring, India $\left(95^{\circ} \mathrm{C}\right.$ ) (Adjeroud et al. 2020, Chan et al. 2017, DeCastro et al. 2021, Padilla-Del Valle et al. 2017, Sharma et al. 2017). Meanwhile, the high abundance of Bacteroidetes phylum was observed in Badi Anhoni hot spring, India $\left(55^{\circ} \mathrm{C}, \mathrm{pH} 7.8\right)$ and Phusang hot spring, Thailand $\left(38^{\circ} \mathrm{C}, \mathrm{pH}\right.$ 7.3) (Bumrungthai et al. 2020, Saxena et al. 2017). Bacteroidetes were less prevalent in hot springs with a temperature above $70^{\circ} \mathrm{C}$ (i.e., Burgas hot spring, Spain; Soldhar hot spring, India; and Sungai Klah, Malaysia $\left(80^{\circ} \mathrm{C}\right)$ (Chan et al. 2015, DeCastro et al. 2021, Sharma et al. 2017).

Family Flavobacteriaceae and its member, genus Cloacibacterium, were the most dominant family and genus in Cangar Hot Spring. The high abundance of Flavobacteriaceae family members was also reported in Brandvlei hot spring, South Africa $\left(55^{\circ} \mathrm{C}, \mathrm{pH} 6.2\right)$, and three hot springs in India, i.e., Yumthang $\left(39^{\circ} \mathrm{C}, \mathrm{pH} 8.0\right)$, Chhoti Anhoni $\left(52.1^{\circ} \mathrm{C}, \mathrm{pH} 7.8\right)$, and Polok $\left(76.3^{\circ} \mathrm{C}, \mathrm{pH}\right.$ 7.5), India (Najar et al. 2018, Panda et al. 2016, Saxena et al. 2017, Selvarajan et al. 2018). The presence of Flavobacteriaceae family members was also reported from other hot springs in Indonesia, i.e., Domas hot spring $\left(90^{\circ} \mathrm{C}, \mathrm{pH} 2\right)$ (Baker et al. 2001). Although the presence of Cloacibacterium in hot springs was reported elsewhere (Kashkak et al. 2016, Selim et al. 2017), to our knowledge, our result is the first observation of its abundance in the hot spring environment. Members of this genus were isolated from wastewater and human skin (Allen et al. 2006, Nouha et al. 2016). Indeed, the main human activities around Cangar Hot Spring were tourism and agriculture, and it might explain the sources of Cloacibacterium in Cangar Hot Spring.

The second most dominant family and genus found were Methylophilaceae and its member, genus Methylobacillus. Family Methylophilaceae is a member of Betaproteobacteria phylum, which includes obligate and facultative methylotrophs Gram-negative rod-shaped bacteria. These bacteria were capable to metabolize $\mathrm{C}_{1}$ compounds (i.e., compounds containing no carboncarbon bonds), mainly methanol or methylamine as a sole source of carbon and energy (Yang et al. 2020, Zhang et al. 2020). Methylophilaceae plays a crucial role in the global carbon cycle in aquatic ecosystems, including hot springs. Methylobacillus was observed in two hot springs in India, i.e., Sholdar (1.88\% of total OTUs) and "Pilgrim Terrace" (1.09\%) (Beck et al. 2014, Chistoserdova et al. 2007, Ghosh et al. 2015, Sharma et al. 2017). Our finding is also the first observation of Methylobacillus abundance in the hot spring ecosystem. 
In previous studies, several species of the genus Bacillus with industrial potential were isolated from Cangar Hot Spring (Chrisnasari et al. 2018, Geraldi et al. 2019b, Ibrahim et al. 2013, Rashid et al. 2013). However, this study suggests that the genus Bacillus was only representing a minor fraction of the total bacteria collected from the Cangar Hot Spring. Compared to Bacillus, there were other potentially useful microorganisms found more abundant in this study. For instance, the second most dominant genus, Methylobacillus, is known as a potential platform used in producing recombinant proteins, amino acids, and other value-added compounds due to their high efficiency in carbon conversion and ability to grow in a relatively cheap and abundant carbon source (methanol) (Agafonova et al. 2018, Beck et al. 2014, Si et al. 2016, Yadava and Maitra 2017). Genus Chitinophaga (1.79\% of total OTUs) is a potential source for chitinase and enzymes related to lignocellulosic material degradation (Kishi et al. 2017, Larsbrink et al. 2017, Sharma et al. 2020). Another potential genus is Hydrogenophaga (1.53\%), with some species members known for their potential in heavy metal oxidation, polycyclic aromatic hydrocarbons, biodegradation, and bioplastic production activities (Fan et al. 2019, Koller et al. 2019, Reddy et al. 2016). The NGS analysis results also identified other useful species, such as biosurfactants-producer Acinetobacter junii and valueadded chemicals-producer Pseudomonas alcaligenes (Dong et al. 2016, Ohadi et al. 2017, Oliveira et al. 2009, Wang et al. 2020). These useful microorganisms present in Cangar Hot Spring are most likely thermotolerant, which is a beneficial characteristic for their application in bioprocess and bioremediation (Nigam 2013).

Besides beneficial microorganisms, NGS analysis results also revealed pathogenic bacteria in the Cangar Hot Spring. Recreational hot springs are known to harbor pathogens associated with human diseases such as Clostridium and Legionella strains (Chan et al. 2015, Ghilamicael et al. 2018). Our results suggested the occurrence of opportunistic pathogens causing bacteremia or the presence of bacteria in the human blood, such as Comamonas testosteroni (3.70\%), Comamonas aquatica (3.54\%), and Vogesella perlucida (0.59\%) (Farooq et al. 2017, Farshad et al. 2012, Kaeuffer et al. 2018, Tartar and Tartar 2020, Tiwari and Nanda 2019, Yu et al. 2020). Furthermore, genus Blautia (3.21\%) and Ruminococcus $(2.86 \%)$, which are related to fecal contamination, were also observed (Devane et al. 2020, Koskey et al. 2014, Staley et al. 2016). The information related to pathogens can develop better health and safety monitoring and risk assessment methods in Cangar Hot Spring.

This study provided insight into the bacterial community structure of the Cangar Hot Spring. The bacterial community composition in the hot spring was dominated by Proteobacteria and Bacteroidetes phyla as other hot springs with moderate temperatures elsewhere. Among others, this study is the first that reported the abundance of genera Cloacibacterium and Methylobacillus. The presence of useful bacteria with the potential to produce enzymes and value-added chemicals, and to involve in the bioremediation process, was also observed.
Likewise, the occurrence of opportunistic pathogens, which is important for the development of health and safety measures in the hot spring, was also reported. As the first effort on using next-generation sequencing in unraveling the microbial diversity in Indonesian hot springs, we expect this study to encourage further exploration in other hot springs in Indonesia.

\section{ACKNOWLEDGEMENTS}

This research and the APC for this publication were funded by Riset Kolaborasi Mitra Luar Negeri Universitas Airlangga Tahun 2020, grant scheme with contract number: 427 /UN3.14/PT/2020.

\section{REFERENCES}

Aditiawati P, Yohandini H, Madayanti F, Akhmaloka. 2009. Microbial diversity of acidic hot spring (kawah hujan B) in geothermal field of Kamojang area, West Java-Indonesia. Open Microbiol J 3: 58-66. DOI: $10.2174 / 1874285800903010058$.

Adjeroud M, Escuder-Rodríguez J-J, González-Siso M-I, Kecha M. 2020. Metagenomic investigation of bacterial and archaeal diversity of hammam essalihine Hot Spring from Khenchela, Algeria. Geomicrobiol J 37: 804-817. DOI: 10.1080/01490451.2020.1783035.

Agafonova N V, Kaparullina EN, Doronina N V, Trotsenko YA. 2018. Obligate methylotroph Methylobacillus arboreus IvaT synthesizes a plant hormone, gibberellic acid GA3. Microbiology 87: 47-50. DOI: 10.1134/S0026261718010022.

Allen TD, Lawson PA, Collins MD, Falsen E, Tanner RS. 2006. Cloacibacterium normanense gen. nov., sp. nov., a novel bacterium in the family Flavobacteriaceae isolated from municipal wastewater. Int J Syst Evol 56: 1311-1316. DOI: 10.1099/ijs.0.64218-0.

Amin A, Ahmed I, Salam N, Kim B-Y, Singh D, Zhi X-Y, Xiao M, Li WJ. 2017. Diversity and distribution of thermophilic bacteria in hot springs of Pakistan. Microb Ecol 74: 116-127. DOI: 10.1007/s00248017-0930-1.

Aminin ALN, Warganegara FM, Aditiawati P, Akhmaloka. 2008. Cultureindependent and culture-dependent approaches on microbial community analysis at Gedongsongo (GS-2) hot spring. Intl J Integr Biol 2: 145-152.

Atalah J, Cáceres-Moreno P, Espina G, Blamey JM. 2019. Thermophiles and the applications of their enzymes as new biocatalysts. Bioresour Technol 280: 478-488. DOI: 10.1016/j.biortech.2019.02.008.

Baker GC, Gaffar S, Cowan DA, Suharto AR. 2001. Bacterial community analysis of Indonesian hot springs. FEMS Microbiol Lett 200: $103-$ 109. DOI: 10.1111/j.1574-6968.2001.tb10700.x.

Beck DAC, McTaggart TL, Setboonsarng U, Vorobev A, Kalyuzhnaya MG, Ivanova N, Goodwin L, Woyke T, Lidstrom ME, Chistoserdova L. 2014. The expanded diversity of Methylophilaceae from Lake Washington through cultivation and genomic sequencing of novel $\begin{array}{lllll}\text { ecotypes. PLOS ONE 9: } 102458 . & \text { DOI: }\end{array}$ 10.1371/journal.pone.0102458.

Bodor A, Bounedjoum N, Vincze GE, Erdeiné Kis Á, Laczi K, Bende G, Szilágyi Á, Kovács T, Perei K, Rákhely G. 2020. Challenges of unculturable bacteria: environmental perspectives. Rev Environ Sci Biotechnol 19: 1-22. DOI: 10.1007/s11157-020-09522-4.

Bumrungthai S, Duangit S, Somsuwan B, Inpeng S. 2020. The chemical characteristic and microbial diversity of the Hot Spring at Phusang National Park. Environ Nat Resour J. 18: 33-43.

Caporaso JG, Kuczynski J, Stombaugh J, Bittinger K, Bushman FD, Costello EK, Fierer N, Pena AG, Goodrich JK, Gordon JI. 2010. QIIME allows analysis of high-throughput community sequencing data. Nat Methods 7: 335-336.

Castro C, Urbieta MS, Plaza Cazón J, Donati ER. 2019. Metal biorecovery and bioremediation: Whether or not thermophilic are better than mesophilic microorganisms. Bioresour Technol 279: $317-$ 326. DOI: 10.1016/j.biortech.2019.02.028. 
Chan CS, Chan K-G, Tay Y-L, Chua Y-H, Goh KM. 2015. Diversity of Thermophiles in a Malaysian Hot Spring determined using 16S rRNA and shotgun metagenome sequencing. Front Microbiol 6: 177. DOI: 10.3389/fmicb.2015.00177.

Chan CS, Chan K-G, Ee R, Hong K-W, Urbieta MS, Donati ER, Shamsir MS, Goh KM. 2017. Effects of physiochemical factors on prokaryotic biodiversity in Malaysian circumneutral Hot Springs. Front Microbiol 8: 1252. DOI: 10.3389/fmicb.2017.01252.

Chistoserdova L, Lapidus A, Han C, Goodwin L, Saunders L, Brettin T, Tapia R, Gilna P, Lucas S, Richardson PM, Lidstrom ME. 2007. Genome of Methylobacillus flagellatus, molecular basis for obligate methylotrophy, and polyphyletic origin of methylotrophy. J. Bacteriol 189: 4020 LP - 4027. DOI: 10.1128/JB.00045-07.

Chrisnasari R, Verina D, Tapatfeto AC, Pranata S, Patjajani T, Wahjudi M, Purwanto MGM. 2018. Isolating and characterising chitinolytic thermophilic bacteria from Cangar Hot Spring, East Java. Pertanika J Trop Agric Sci 41: 1437-1448

Darma S, Harsoprayitno S, Setiawan B, Hadyanto, Sukhyar R, Soedibjo AW, Ganefianto N, Stimac J. 2010. Geothermal energy update: geothermal energy development and utilization in Indonesia. In World Geothermal Congress. Bali, 25-29 April 2010.

Daryono MR, Natawidjaja DH, Sapiie B, Cummins P. 2019. Earthquake Geology of the Lembang Fault, West Java, Indonesia. Tectonophysics 751: 180-191. DOI: 10.1016/j.tecto.2018.12.014.

Daud Y, Nuqramadha WA, Fahmi F, Sesesega RS, Fitrianita, Pratama SA Munandar A. 2019. Resistivity characterization of the ArjunoWelirang volcanic geothermal system (Indonesia) through 3-D Magnetotelluric inverse modeling. J Asian Earth Sci 174: 352-363. DOI: $10.1016 /$ j.jseaes.2019.01.033

DeCastro M-E, Doane MP, Dinsdale EA, Rodríguez-Belmonte E, González-Siso M-I. 2021. Exploring the taxonomical and functional profile of As Burgas hot spring focusing on thermostable $\beta$ galactosidases. Sci Rep 11: 101. DOI: 10.1038/s41598-020-80489-6.

Devane M, Robson B, Lin S, Scholes P, Wood D, Weaver L, WebsterBrown J, Gilpin B. 2020. Bacterial community shifts in decomposing cowpats and the subsequent impacts on fecal source indicators for water quality monitoring. Ecol Indic 113: 106239. DOI: 10.1016/j.ecolind.2020.106239.

Di Donato P, Finore I, Poli A, Nicolaus B, Lama L. 2019. The production of second-generation bioethanol: The biotechnology potential of thermophilic bacteria. J Clean Prod 233: 1410-1417. DOI 10.1016/j.jclepro.2019.06.152.

Dong H, Xia W, Dong H, She Y, Zhu P, Liang K, Zhang Z, Liang C, Song Z, Sun S, Zhang G. 2016. Rhamnolipids produced by indigenous Acinetobacter junii from petroleum reservoirs and its potential in enhanced oil recovery. Front Microbiol 7: 1710. DOI: 10.3389/fmicb.2016.01710

Ebaid R, Wang H, Sha C, Abomohra AE-F, Shao W. 2019. Recent trends in hyperthermophilic enzymes production and future perspectives for biofuel industry: A critical review. J Clean Prod 238: 117925. DOI 10.1016/j.jclepro.2019.117925

Edgar RC. 2004. MUSCLE: multiple sequence alignment with high accuracy and high throughput. Nucleic Acids Res 32: 1792-1797.

Edgar RC. 2013. UPARSE: highly accurate OTU sequences from microbial amplicon reads. Nat Methods 10: 996-998.

Edgar RC, Haas BJ, Clemente JC, Quince C, Knight R. 2011. UCHIME improves sensitivity and speed of chimera detection. Bioinformatics 27: $2194-2200$

Fan X, Nie L, Shi K, Wang Q, Xia X, Wang G. 2019. Simultaneous 3-/4 hydroxybenzoate biodegradation and arsenite oxidation by Hydrogenophaga sp. H7. Front Microbiol 10: 1346. DOI: 10.3389/fmicb.2019.01346

Farooq S, Farooq R, Nahvi N. 2017. Comamonas testosteroni: Is it still a rare human pathogen. Case Rep Gastroenterol 11: 42-47. DOI: $10.1159 / 000452197$

Farshad S, Norouzi F, Aminshahidi M, Heidari B, Alborzi A. 2012. Two cases of bacteremia due to an unusual pathogen, Comamonas testosteroni in Iran and a review literature. J Infect Dev Ctries 6. DOI: $10.3855 /$ jidc. 2215 .

Geraldi A, Azzahra A, Asritafriha L, Zain RA. 2019a. Biosurfactant production using bacterial isolate from Cangar Hot Spring, East Java, Indonesia. Ecol Environ Conserv 25: S75-S79.

Geraldi A, Ni'matuzahroh, Wanguyun AP, Hariyanto S, Agustiana BND, Nastiti A, Alfiyanita RN, Gumilar I, Virginia TT, Mukarromah SR, Savitri AD, Nadhiva EE, Jallaludhin K, Kinayoh LR. 2019b.
Bioprospecting of cellulolytic and biosurfactant-producing bacteria for organic waste treatment. Pollut Res 38: S114-S117.

Geraldi A, Wanguyun AP, Hariyanto S. 2019c. Bioprospecting thermostable enzymes-producing thermophiles from Indonesia. Ecol Environ Conserv 25: S75-S79.

Ghilamicael AM, Boga HI, Anami SE, Mehari T, Budambula NLM. 2018. Potential human pathogenic bacteria in five hot springs in Eritrea Revealed by Next Generation Sequencing. PLOS ONE 13: e0194554. DOI: 10.1371/journal.pone.0194554.

Ghosh W, Roy C, Roy R, Nilawe P, Mukherjee A, Haldar PK, Chauhan NK, Bhattacharya S, Agarwal A, George A, Pyne P, Mandal S, Rameez MJ, Bala G. 2015. Resilience and receptivity worked in tandem to sustain a geothermal mat community amidst erratic environmental conditions. Sci Rep 5: 12179. DOI: 10.1038/srep12179

Haas BJ, Gevers D, Earl AM, Feldgarden M, Ward D V, Giannoukos G, Ciulla D, Tabbaa D, Highlander SK, Sodergren E. 2011. Chimeric $16 \mathrm{~S}$ rRNA sequence formation and detection in Sanger and 454pyrosequenced PCR amplicons. Genome Res 21: 494-504.

Huber G, Huber R, Jones BE, Lauerer G, Neuner A, Segerer A, Stetter KO, Degens ET 1991. Hyperthermophilic Archaea and Bacteria occurring within Indonesian hydrothermal areas. Syst Appl Microbiol 14: 397-404. DOI: 10.1016/S0723-2020(11)80317-6

Ibrahim D, Li Zhu H, Yusof N, Isnaeni, Sheh Hong L. 2013. Bacillus licheniformis BT5.9 isolated from Changar Hot Spring, Malang, Indonesia, as a potential producer of thermostable $\alpha$-amylase. Trop Life Sci Res 24: 71-84.

Jardine JL, Stoychev S, Mavumengwana V, Ubomba-Jaswa E. 2018. Screening of potential bioremediation enzymes from hot spring bacteria using conventional plate assays and liquid chromatography Tandem mass spectrometry (Lc-Ms/Ms). J Environ Manag 223: 787796. DOI: $10.1016 /$ j.jenvman.2018.06.089.

Jiang L, Lin M, Zhang Y, Li Y, Xu X, Li S, Huang H. 2013. Identification and characterization of a novel trehalose synthase gene derived from saline-alkali soil metagenomes. PLoS ONE 8: e77437. DOI: 10.1371/journal.pone.0077437.

Jiang Z, Xu T, Mariethoz G. 2018. Numerical investigation on the implications of spring temperature and discharge rate with respect to the geothermal background in a fault zone. Hydrogeol J 26: 21212132. DOI: $10.1007 / \mathrm{s} 10040-018-1769-3$

Kaeuffer C, Schramm F, Meyer A, Hansmann Y, Guffroy A, Argemi X. 2018. First case of Comamonas aquatica bacteremia complicated by septic shock. Med Mal Infect 48: 540-542.

Kambourova M. 2018. Thermostable enzymes and polysaccharides produced by thermophilic bacteria isolated from Bulgarian hot springs. Eng Life Sci 18: 758-767. DOI: 10.1002/elsc.201800022.

Kashkak ES, Bel'kova NL, Danilova E V, Dagurova OP, Namsaraev BB, Gorlenko VM. 2016. Phylogenetic and functional prokaryotic diversity in the Hoito-Gol mesothermal mineral spring (Eastern Sayan Mountains, Buryat Republic). Microbiology 85: 592-603. DOI: $10.1134 / \mathrm{S} 0026261716050076$

Kishi LT, Lopes EM, Fernandes CC, Fernandes GC, Sacco LP, Carareto Alves LM, Lemos EGM. 2017. Draft genome sequence of a Chitinophaga; strain isolated from a lignocellulose biomassdegrading consortium. Genome Announc 5: e01056-16. DOI: 10.1128/genomeA.01056-16.

Koller M, Hesse P, Braunegg G. 2019. Application of whey retentate as complex nitrogen source for growth of the polyhydroxyalkanoate producer Hydrogenophaga pseudoflava strain DSM1023. EuroBiotech J 3: 78-89. DOI: 10.2478/ebtj-2019-0009

Koskey AM, Fisher JC, Eren AM, Ponce-Terashima R, Reis MG, Blanton RE, McLellan SL. 2014. Blautia and Prevotella sequences distinguish human and animal fecal pollution in Brazil surface waters. Environ Microbiol Rep 6: 696-704. DOI: 10.1111/1758-2229.12189.

Larsbrink J, Tuveng TR, Pope PB, Bulone V, Eijsink VGH, Brumer H, McKee LS. 2017. Proteomic insights into mannan degradation and protein secretion by the forest floor bacterium Chitinophaga pinensis. J Proteom 156: 63-74. DOI: 10.1016/j.jprot.2017.01.003.

Li L, Li W, Zou Q, Ma Z (Sam.. 2020. Network analysis of the hot spring microbiome sketches out possible niche differentiation among ecological guilds. Ecol Modell 431: 109147. DOI: 10.1016/j.ecolmodel.2020.109147.

Lischer K, Putra ABRD, Guslianto BW, Avila F, Sitorus SG, Nugraha Y. 2020. The emergence and rise of indigenous thermophilic bacteria exploration from hot springs in Indonesia. Biodiversitas 21: 54745481. DOI: $10.13057 /$ biodiv/d211156 
Di Lorenzo F, Paciello I, Fazio LL, Albuquerque L, Sturiale L, da Costa MS, Lanzetta R, Parrilli M, Garozzo D, Bernardini ML. 2014 Thermophiles as potential source of novel endotoxin antagonists: the full structure and bioactivity of the lipo-oligosaccharide from Thermomonas hydrothermalis. ChemBioChem 15: 2146-2155.

Magoč T, Salzberg SL. 2011. FLASH: fast length adjustment of short reads to improve genome assemblies. Bioinformatics 27: 2957-2963.

Mahajan GB, Balachandran L. 2017. Sources of antibiotics: Hot springs. Biochem Pharmacol 134: 35-41. DOI: 10.1016/j.bcp.2016.11.021

Martadiastuti V, Harijoko A, Warmada IW, Yonezu K. 2017. Hydrogeochemical characterization of geothermal water in ArjunoWelirang, East Java, Indonesia. J Appl Geol 2: 59-69.

Najar IN, Sherpa MT, Das S, Das S, Thakur N. 2018. Microbial ecology of two hot springs of Sikkim: Predominate population and geochemistry. Sci Total Environ 637-638: 730-745. DOI: 10.1016/j.scitotenv.2018.05.037.

Nigam PS. 2013. Microbial enzymes with special characteristics for biotechnological applications. Biomolecules 3: 597-611.

Nouha K, Kumar RS, Tyagi RD. 2016. Heavy metals removal from wastewater using extracellular polymeric substances produced by Cloacibacterium normanense in wastewater sludge supplemented with crude glycerol and study of extracellular polymeric substances extraction by different methods. Bioresour Technol 212: 120-129. DOI: 10.1016/j.biortech.2016.04.021.

Ohadi M, Forootanfar H, Rahimi HR, Jafari E, Shakibaie M, Eslaminejad T, Dehghannoudeh G. 2017. Antioxidant potential and wound healing activity of biosurfactant produced by Acinetobacter junii B6. Curr Pharm Biotechnol 18: 900-908. DOI: $10.2174 / 1389201018666171122121350$

Oliveira FJS, Vazquez L, de Campos NP, de França FP. 2009. Production of rhamnolipids by a Pseudomonas alcaligenes strain. Process Biochem 44: 383-389. DOI: 10.1016/j.procbio.2008.11.014

Orellana R, Macaya C, Bravo G, Dorochesi F, Cumsille A, Valencia R, Rojas C, Seeger M. 2018. Living at the Frontiers of Life: Extremophiles in Chile and their potential for bioremediation. Front Microbiol 9: 2309. DOI: 10.3389/fmicb.2018.02309.

Padilla-Del Valle R, Morales-Vale LR, Ríos-Velázquez C. 2017 Unraveling the microbial and functional diversity of Coamo thermal spring in Puerto Rico using metagenomic library generation and shotgun sequencing. Genom Data 11: 98-101. DOI 10.1016/j.gdata.2016.12.010.

Panda AK, Bisht SS, De Mandal S, Kumar NS. 2016. Bacterial and archeal community composition in hot springs from Indo-Burma region, North-east India. AMB Express 6: 111. DOI: 10.1186/s13568016-0284-y

Pentecost A, Jones B, Renaut RW. 2003. What is a hot spring? Can J Earth Sci 40: 1443-1446. DOI: 10.1139/e03-083.

Purnomo BJ, Pichler T. 2014. Geothermal systems on the island of Java, Indonesia. J Volcanol Geotherm Res 285: 47-59. DOI 10.1016/j.jvolgeores.2014.08.004.

Putra RPM, Sutopo, Pratama HB. 2019. Improved natural state simulation of Arjuno-Welirang Geothermal field, East Java, Indonesia. IOP Conf Ser Earth Environ Sci 254: 12022. DOI: 10.1088/17551315/254/1/012022.

Quast C, Pruesse E, Yilmaz P, Gerken J, Schweer T, Yarza P, Peplies J, Glöckner FO. 2012. The SILVA ribosomal RNA gene database project: improved data processing and web-based tools. Nucleic Acids Res 41: D590-D596.

Rashid FAA, Rahim RA, Ibrahim D, Balan A, Bakar NMA. 2013 Purification and properties of thermostable lipase from a thermophilic bacterium, Bacillus licheniformis IBRL-CHS2. J Pure Appl Microbiol 7: 1635-1645.

Sahoo K, Sahoo RK, Gaur M, Subudhi E. 2020. Cellulolytic thermophilic microorganisms in white biotechnology: a review. Folia Microbiol 65: 25-43. DOI: 10.1007/s12223-019-00710-6.

Saxena R, Dhakan DB, Mittal P, Waiker P, Chowdhury A, Ghatak A, Sharma VK. 2017. Metagenomic analysis of hot springs in Centra India reveals hydrocarbon-degrading thermophiles and pathways essential for survival in extreme environments. Front Microbiol 7 : 2123. DOI: $10.3389 /$ fmicb.2016.02123.

Schloss PD, Westcott SL, Ryabin T, Hall JR, Hartmann M, Hollister EB, Lesniewski RA, Oakley BB, Parks DH, Robinson CJ, Sahl JW, Stres
B, Thallinger GG, Van Horn DJ, Weber CF. 2009. Introducing mothur: Open-source, platform-independent, community-supported software for describing and comparing microbial communities. Appl Environ Microbiol 75: 7537 LP - 7541. DOI: 10.1128/AEM.01541-09 Selim S, Hassan S, Hagagy N, Kraková L, Grivalský T, Pangallo D. 2017. Assessment of microbial diversity in Saudi Springs by culturedependent and culture-independent methods. Geomicrobiol J 34: 443453. DOI: $10.1080 / 01490451.2016 .1219430$.

Selvarajan R, Sibanda T, Tekere M. 2018. Thermophilic bacterial communities inhabiting the microbial mats of "indifferent" and chalybeate (iron-rich) thermal springs: Diversity and biotechnological analysis. MicrobiologyOpen 7: e00560. DOI: DOI: $10.1002 / \mathrm{mbo} 3.560$

Sharma A, Paul D, Dhotre D, Jani K, Pandey A, Shouche YS. 2017. Deep sequencing analysis of bacterial community structure of Soldhar Hot Spring, India. Microbiology 86: 136-142. DOI: 10.1134/S0026261717010118

Sharma S, Kumar S, Khajuria A, Ohri P, Kaur R, Kaur R. 2020. Biocontrol potential of chitinases produced by newly isolated Chitinophaga sp. S167. World J Microbiol Biotechnol 36: 90. DOI: 10.1007/s11274-020-02864-9.

Si Z, Zhu J, Wang W, Huang L, Wei P, Cai J, Xu Z. 2016. Novel and efficient screening of PQQ high-yielding strains and subsequent cultivation optimization. Appl Microbiol Biotechnol 100: 1032110330. DOI: 10.1007/s00253-016-7739-6.

Staley ZR, Grabuski J, Sverko E, Edge TA. 2016. Comparison of microbial and chemical source tracking markers to identify fecal contamination sources in the Humber River (Toronto, Ontario, Canada) and associated storm water outfalls. Appl Environ Microbiol 82: 6357 LP - 6366. DOI: 10.1128/AEM.01675-16.

Tartar AS, Tartar T. 2020. A rare pathogen in acute appendicitis: two cases with Comamonas testosteroni infection and literature review. J Pediatr Infect Dis 15: 110-112.

Teta R, Marteinsson VT, Longeon A, Klonowski AM, Groben R, Bourguet-Kondracki M-L, Costantino V, Mangoni A. 2017. Thermoactinoamide A, an antibiotic lipophilic cyclopeptide from the Icelandic thermophilic bacterium Thermoactinomyces vulgaris. J Nat Prod 80: 2530-2535. DOI: 10.1021/acs.jnatprod.7b00560

Tiwari S, Nanda M. 2019. Bacteremia caused by Comamonas testosteroni an unusual pathogen. J Lab Phys 11: 87-90. DOI: 10.4103/JLP.JLP 11618

Reddy MV, Mawatari Y, Yajima Y, Satoh K, Venkata Mohan S, Chang Y-C. 2016. Production of poly-3-hydroxybutyrate (P3HB) and poly(3-hydroxybutyrate-co-3-hydroxyvalerate) $\mathrm{P}(3 \mathrm{HB}-\mathrm{co}-3 \mathrm{HV})$ from synthetic wastewater using Hydrogenophaga palleronii. Bioresour Technol 215: 155-162. DOI: 10.1016/j.biortech.2016.03.025

Wang S, Lin X, Huang X, Zheng L, Zilda DS. 2012. Screening and characterization of the alkaline protease isolated from PLI-1, a strain of Brevibacillus sp. collected from Indonesia's hot springs. J Ocean Univ China 11: 213-218. DOI: 10.1007/s11802-012-1845-6

Wang S, Cui J, Bilal M, Hu H, Wang W, Zhang X. 2020. Pseudomonas spp. as cell factories (MCFs) for value-added products: from rational design to industrial applications. Crit Rev Biotechnol 40: 1232-1249. DOI: $10.1080 / 07388551.2020 .1809990$

Yadava S, Maitra SS. 2017. Molecular detection of Methylotrophs from an Indian landfill site and their potential for biofuel production. Global Nest J 19: 533-539.

Yang Y, Wang H, Zheng Y, Zhu B, Wu X, Zhao F. 2020. Extracellular electron transfer of Methylophilus methylotrophs. Process Biochem 94: 313-318. DOI: 10.1016/j.procbio.2020.05.001

Yohandini H, Julinar, Muharni. 2015. Isolation and phylogenetic analysis of thermophile community within Tanjung Sakti Hot Spring, South Sumatera, Indonesia. Hayati J Biosci 22: 143-148. DOI: 10.1016/j.hjb.2015.10.006

Yu Z, Zhu F, Tao X, Zhang L, Wu S, Dong C, Dong Y, Chen G, Zhou X, Fang Y, Xu K. 2020. Vogesella perlucida-induced bacteremia in an advanced-age patient: first case report. BMC Infect Dis 20: 687. DOI: 10.1186/s 12879-020-05420-w.

Zhang R, Liu W, Liu Y, Zhang H, Zhao Z, Zou L, Shen Y, Lan W-S. 2020. Impacts of anthropogenic disturbances on microbial community of coastal waters in Shenzhen, South China. Ecotoxicology. DOI: 10.1007/s 10646-020-02297-y. 